\title{
Serum Immunoglobulin Changes in Pregnancy Complicated with Pre-Eclampsia and Diabetes in Nigerian Women
}

\author{
Amah-Tariah F.S.; Dapper, V. D.; Olorunfemi O.J. and Osunwoke E. A. ${ }^{1}$ \\ Department of Human Physiology, ${ }^{1}$ Department of Human Anatomy, Faculty of Basic Medical Sciences, \\ College of Health Sciences, University of Port Harcourt, Port Harcourt, Nigeria.
}

\begin{abstract}
:
Objectives: Serum concentrations of $\operatorname{IgA}, \operatorname{IgG}$ and IgM were determined in subjects with pre-eclampsia and gestational diabetes as compared to both apparently healthy pregnant and non-pregnant subjects resident in Port Harcourt, Nigerian.

Materials and methods: A total of 200 femalesubjects comprising four groups of 50 subjects each were recruited into the study: healthy non-pregnant subjects (Group A); healthy pregnant subjects (Group B); subjects with pre-eclampsia (Group $C$ ) and subjects with gestational diabetesmellitus (Group D). All pregnant subjects were further subdivided into the appropriate semester according to gestational age of pregnancy. Venousblood samples were obtained and determined for immunoglobulins $A, G$ and $M$ with theturbidimetric immunoassay method usingan automated chemical analyzer.

Results: Significant differences were observed in the values of the various types of immunoglobulins studied between healthy HIV sero-negative non-pregnant (group A) subjects and healthy HIV sero-negative pregnant (group B) subjects. Noteworthy is the observation that the values of both IgG and IgM were significantly higher while the values of IgA were significantly lower amongst the non-pregnant subjects in group A, compared to all the other pregnant subject groups: $B, C$ and $D(p<0.05)$. Furthermore, group B subjects were found to have significantly higher values of IgG and lower levels of IgM compared to groups $C$ and D subjects $(p<0.05)$. Values of IgA were significantly higher $(P<0.05)$ in all pregnant groups compared to the non-pregnant subjects but highest in the GDM (group D) women.During the course of gestation, a graded decrease in the mean values of all three immunoglobulin classes was observed in the healthy pregnant group from the $1^{\text {st }}$ to $3^{\text {rd }}$ trimester. However, whereas a graded increase in mean IgA and IgM were observed in group C subjects across trimesters, mean IgG showed a similar graded but significant decrease ( $P<0.05)$. Also, the mean IgG decreased significantly in the pregnant diabetic $(D)$ group in the $2^{\text {nd }}$ trimester,but that of IgM significantly increased in the $2^{\text {nd }}$ trimester

Conclusion: The observed changes in immunoglobulins $A, G$ and $M$ levels may be indicative of poorly transferred secondary immunity in the children born to pregnant diabetic and pre-eclamptic women, as well as pose complications related to indirect immune responses in these conditions.
\end{abstract}

Keywords: Immunoglobulins, Pregnancy, Women, Diabetes, Pre-eclampsia

\section{Introduction}

Suppression of maternal immune response may be one of the factors contributing to continuation of pregnancy, a state in which the foetus exists as a well-tolerated homograft. Studies on serum immunoglobulin levels in pregnancy have shownvarying results (Fischbach, 2009). In some, serum IgG levels showed a graded significant decrease in normal pregnancy compared to the non-pregnant population; IgM levels rose in late pregnancy while IgA increased with pregnancy (Benster and Wood, 1970; Khirwadkaret al, 1991). In other studies, IgG and IgM declined progressively throughout gestation with a tremendous significant decrease between the first and second trimesters and between the second and third trimesters in pregnant women than those of age-matched non-pregnant control subjects, There was also a significant decrease between the second and third trimester groups, however, no statistical difference was observed for IgA levels throughout normal pregnancy (Miller et al., 1984;Ogbimi and Onu, 1989; Arinolaet al, 2006).

Yet in some other studies, the mean $\operatorname{IgG}$ and $\operatorname{IgM}$ levels markedly increased in pregnant women,especially $\operatorname{IgG}$ concentration, in the final trimester of pregnancy, which is in association with enhanced IgG transport through the placenta to the fetus during late pregnancy period(NoorAl-Hayani, 2011).

Comparing immunoglobulins between normal and complicated pregnancies revealed differing outcomes. Marked reduction in $\operatorname{IgG}$ and $\operatorname{Ig}$ A levels have been observed in women with preeclampsia, while $\operatorname{IgA}$ levels were similar in both healthy and pre-eclampticgroups (Jillimi, 1978); depression of IgG and complement C3 levels in maternal and cord sera of mothers with pregnancy induced hypertension (PIH) was also observed, suggesting decreased immunological status of both mother and offspring in pre-eclampsia, irrespective of gestation and intrauterine growth status (Ramdeneeet al., 1995); Ahsan et al (2009) 
Studies on haematological parameters including immunoglobulins in pregnancy have been relatively parsimonious, especially in Southeastern Nigeria. However, previous and ongoing studies from our centre have aimed at establishing reference ranges and normative values for various haemorrheological and immunological parameters in children and adults as well as in pregnancy and some pregnancy complications (Okerengwo et al, 1990; Dapper et al, 2008; Dapper et al, 2009; Amah-Tariah et al, 2011; Obiandu et al, 2013).

This study is particularly aimed at evaluating thelevels of immunoglobulins A, G and M to ascertain changes in apparently healthy pregnancy and in pregnancy complicated with pre-eclampsia and diabetes mellitus amongst Nigerian women resident in Port Harcourt.

\section{Subjects:}

\section{Subjects and methods}

A total of 200female subjectswere randomly recruited from amongst patients attending the ante-natal and general out-patient clinics of a number of primary, secondary and tertiary health care institutions in Port Harcourt, Nigeria. Female staff of these institutions who were non pregnant and apparently healthy were recruited as controls. The subjects were aged between 18 and 40 years and were of various socio-economic classes and ethnic groups resident in southeastern Nigeria. No subject had any other co-existing abnormality and none had previously received any form of blood transfusion. The subjects were divided into 4 groups with each group consisting of 50 subjects:

Group A: healthy non-pregnant subjects

Group B: healthy pregnant subjects

Group C: subjects with pre-eclampsia (PE) and;

Group D: subjects with gestational diabetes mellitus (GDM).

Depending on the duration of pregnancy, subjects in groups B, C and D were divided further into three subgroups: first, second and third trimester. For the present study, the first trimester was considered to end at the thirteenth week, the second trimester to end at the twenty-sixth week and the third trimester to end at forty weeks (Amah-Tariahet. al., 2011).

The diagnosis of pre-eclampsia was made on the detection of a blood pressure level exceeding 140/90 mmHgwith proteinuria greater than $0.3 \mathrm{~g} / 24 \mathrm{~h}$ after20 weeks' gestation (Brown et al., 2001).Gestational diabetes was determined according to WHO's (2013) recommendation for the diagnosis of GDM: a 2-hour plasma glucose $8.5-11.0 \mathrm{mmol} / \mathrm{l}(153-199 \mathrm{mg} / \mathrm{dl})$ following a $75 \mathrm{~g}$ oral glucose load or fasting plasma glucose 5.1-6.9 mmol/l (92-125 mg/dl) or both. The study was approved by our institutional ethics committee and informed consent sought and obtained from each subject prior to recruitment.

\section{Blood collection:}

$5 \mathrm{ml}$ of venous bloodwas carefully collected from an ante-cubital vein with the subject comfortably seated and with minimal stasis. The blood was transferred into anticoagulant free sample bottlesappropriately labelled andallowed to coagulate. The samples were centrifuged,serum obtained and stored at $-20^{\circ} \mathrm{C}$ until ready for immunoglobulin assay. All assays were done within two weeks of blood collection.

\section{Assay of immunoglobulin levels:}

Serum levels of immunoglobulins A, G and M was determined using the immunoturbidimetric assay method with a fully smart automated clinical chemistry analyzer (Biochemical Systems International Srl, Italy), Clindiag system B.V.B.A immunoglobulin reagent kits and immunoglobulins A, G and M kits (Belgium, Germany).

\section{Immunoturbidimetric method:}

The principle of immunoturbidimetric method involves determination of immunoglobulin concentration through photometric measurement of immune complexes between antibodies of immunoglobulin and immunoglobulin present in the samples, the absorbency of which is directly proportional to the concentration of the immunoglobulin.

Preparation of reagent was done using the serum start method: the Clindiag reagent components, R1 (100mmol/L Tris butter, 50g/LPEG6000) and R2 (100mmol/L Tris butter, 50g/L PEG 6000, antiimmunoglobulin antibody) were mixed in a ratio of 3:1 to produce a working solution which was dispensed into appropriately labelled reagent bottles and placed in the automated analyser's reagent tray.Diluent bottles were filled with distilled water. Blood samples were subsequently thawed and labelled appropriately.Assay procedure was programmed on fully smart chemistry analyser using multi standard programmes method and test identification was entered for $\operatorname{IgA}, \operatorname{IgG}$ and IgM. Assay conditions were set accordingly: $340 \mathrm{~nm}$ and $670 \mathrm{~nm}$ main wavelength and sub-wavelength respectively, $37^{\circ} \mathrm{C}$ temperature, cuvette light path of $1.0 \mathrm{~cm}$ and 
absorbance range of 0-0.25A. Samples were dispensed into analyser's sample cups using automatic micropipette and placed in appropriate positions in the analyser's sample tray.Calibrations were made at manufacturer's specifications for automated chemistry analyser: IgA- $4.5 \mathrm{~g} / \mathrm{L}, \mathrm{IgG}-26 \mathrm{~g} / \mathrm{L}$ and IgM- $2.5 \mathrm{~g} / \mathrm{L}$.A graph of absorbance versus concentration for each standard was plotted to obtain a standard calibration curve which was used to determine immunoglobulin concentration.

\section{Statistical analysis:}

The results obtained were presented in Tables 1 and 2 . All values are presented as mean \pm standard deviation. Significant differences in the values of immunoglobulins isotypes between groups were determined using ANOVA. A p <0.05 was considered significant.

\section{Results}

Table 1 shows the values of the various immunoglobulin types obtained for all subjects involved in the present study.Significant differences were observed in the values between healthy non-pregnant (group A) subjects and healthy pregnant (group B)subjects. For instance, the value of IgG and IgM amongst group A subjects was $3615.92 \pm 261.50 \mathrm{mg} / \mathrm{dl}$ and $238.68 \pm 38.38 \mathrm{mg} / \mathrm{dl}$ respectively, these were found to significantly higher than the corresponding values amongst group B subjects which were: $1529.00 \pm 88.11 \mathrm{mg} / \mathrm{dl}$ and $136.20 \pm 23.89 \mathrm{mg} / \mathrm{dl}$ for $\mathrm{IgG}$ and $\mathrm{IgM}$ respectively; while values of $\operatorname{IgA}$ for group B subjects found to be $130.24 \pm 14.0 \mathrm{mg} / \mathrm{dl}$ was significantly higher than the corresponding value amongst group A subjects found to be $119.76 \pm 16.794 \mathrm{mg} / \mathrm{dl}(\mathrm{p}<0.05)$. Noteworthy is the observation that the values of both $\operatorname{IgG}$ and IgM were significantly higher while the values of IgA were significantly lower amongst thenon-pregnant subjects in group A compared to all the other pregnant subject groupsin $B, C$ and $D(p<0.05)$.

For the pregnant women with pre-eclampsia (Group C), whereas the mean IgG and IgM levels decreased significantly (IgG: $1366.67 \pm 67.26$; IgM: $172.67 \pm 29.19$ ), the change in the mean IgA level was insignificant $(\mathrm{P}>0.05)$ when compared to the healthy pregnant group (Group B). Also, significant increase $(\mathrm{P}<0.05)$ in $\mathrm{IgA}$ mean levels $(177.13 \pm 20.47)$ were observed in the subjects with GDM (Group D) when compared to both the non-pregnant and the healthy pregnant subjects (Groups A and B).Further, whereasthe mean $\operatorname{IgG}(1207.06 \pm 22.51)$ and $\operatorname{IgM}(195.40 \pm 20.67)$ levelsfor group D wereobserved to be significantly lower $(\mathrm{P}<0.05)$ than those of the healthy non-pregnant and healthy pregnant groups (Groups A and B), the mean IgM level was significantly higher than the healthy pregnant subjects $(136.20 \pm 23.89 \mathrm{mg} / \mathrm{dl})$ but lower than the nonpregnant subjects $(238.68 \pm 38.38 \mathrm{mg} / \mathrm{dl})$.Values of these immunoglobulin types are as shown in Table 1 .

Table 2a shows the values of immunoglobulin A (IgA) obtained at the various trimesters of pregnancy amongst all the pregnant subjects of groups $\mathrm{B}, \mathrm{C}$ and $\mathrm{D}$. There was a significant increase $(\mathrm{P}<0.05)$ in mean $\mathrm{IgA}$ level between the second $(192.12 \pm 27.30)$ and third trimester(233.09+13.18) in group C (pre-eclamptic) subjects. Table $2 \mathrm{~b}$ and Table $2 \mathrm{c}$ show values of immunoglobulin $\mathrm{G}(\mathrm{IgG})$ and immunoglobulin $\mathrm{M}(\operatorname{IgM})$ respectively obtained at the various trimesters of pregnancy amongst all the pregnant subjects of groups B, C and D. A graded decrease in the mean values of all three immunoglobulin classes were observed in the healthy pregnant women (group B) from the $1^{\text {st }}$ to $3^{\text {rd }}$ trimester. However, whereas a graded increase in mean $\operatorname{IgA}$ and IgM were observed in the pre-eclamptic women between the $2^{\text {nd }}$ and $3^{\text {rd }}$ trimesters, their mean IgG showed a reverse graded significant decrease $(\mathrm{P}<0.05)$. Further, in the pregnant diabetic (D) group, mean IgG and IgMlevels exhibited contrasting trends across trimesters; whereas $\mathrm{IgG}$ decreased in the $2^{\text {nd }}$ trimester, and then, increased in the $3^{\text {rd }}$ trimester, IgM increased in the $2^{\text {nd }}$ trimester and then, decreased in the $3^{\text {rd }}$ trimester. It is noteworthy that only 4 of the 50 subjects in group D were diagnosed in the first trimester.

\section{Discussion}

Usually, pregnancy is associated with certain maternal physiological changes including a well over $10 \%$ increase in body weight, $20 \%$ increase in blood volume, increased metabolic rates as well as other systemic changes including the immune system (Rhoades and Bell, 2013).Several health conditions including pregnancy and the presence of disease(s) affect the immune system of the individual (Akinpeluet al., 2012). Khirwadkar and Kher, (1991), reported that for positive outcome of a normal pregnancy, there must be stability and mild suppression of the maternal immune response. The report explained that it is one factor that allows the foetus to exist as a well-tolerated homograft. However, the event of markedly increased or decreased immune responses in pregnancy may result in some forms of complexities (Fischbach, 2009). In the submissions of WHO/JUNP(1998), not only is the immune function affected in disease conditions in non-pregnant states but much severe during pregnancy.

Expectedly, the mean levels of the most abundant immunoglobulins, IgG and IgM, were found to be drastically reduced in the normal pregnant subjects when compared to the non-pregnant subjects. IgA, on the other hand, was significantly increased in the normal pregnant group relative to the non-pregnant women. This result has a slight variance from that reported by Arinolaet al (2006) in the same Nigerian women, who 
Serum Immunoglobulin Changes In Pregnancy Complicated With Pre-Eclampsia And Diabetes...

observed that the mean level of $\operatorname{IgG}$ and IgA were significantly higher in subjects with normal pregnancy when compared with non-pregnant controls. This finding, in accordance with that by Malek (2013), proves that during human pregnancy, the maternal immune system is suppressed to allow for protection for the growing placenta and foetus. By this submission, it is clear that for a successful outcome of pregnancy, the sensitivity of the maternal immunity is reduced in order to tolerate the developing allograft. This would also mean that, magnification in the immunoglobulin levels due to the impacts of any possible underlying disease condition may result in immune related complicationsin pregnancy, since the immunoglobulins levels are supposed to be lower in pregnancy.

Emerging data on the pathogenesis of pre-eclampsia, a common disorder in pregnancyassociated with high maternal morbidity and mortality and intrauterine fetal growth restriction, has revealed a reduction in the uteroplacental blood flow resulting from the toxic combination of hypoxia, imbalance of angiogenic and antiangiogenic factors, inflammation and deranged immunity (Eilandet al, 2012). The results of the current study also showed graded significant increases in both $\operatorname{IgA}$ and IgM mean levels in preeclampsia, but a significant depression in mean $\mathrm{IgG}$ concentration from the $2^{\text {nd }}$ to $3^{\text {rd }}$ trimester. Though rare, $1^{\text {st }}$ trimester preeclamptic subjects were not detected in the present study, this may be due to a delayed registration for antenatal care by pregnant women in our environment. This was similar to the observation by Ahsan et al (2009). Hence early detection of pre-eclampsia is one of the most important goals in obstetrics in view of its associated complications on the cardiovascular system, respiratory system, liver and kidneys (Al-Jameil, 2014; ReemMustafa et al, 2012).

Diabetes has been reported to have deleterious effects on pregnancy (Georgieff, 2006).A markedly significant rise $(\mathrm{P}<0.05)$ in mean $\operatorname{IgA}$ and $\operatorname{IgM}$, with a concomitant depression in mean $\operatorname{IgG}$ was observed in the diabetic subjects as related to the normal pregnant women. This observation is in agreement with other studies where hyperglycaemiachanges antibody production in pregnant women, and that altered levels of plasma glucose may decrease immunoglobulin production (Eduardo et al., 2012). High levels of IgA may indicate the presence of some form of autoimmune diseases and liver diseases, such as cirrhosis and long-term (chronic) hepatitis or others. Going by this submission, the increase in both IgA and IgM levels in the diabetic subjects may be an indirect response of the immune system to the effects of diabetes on other organs or systems of the body Fischbach (2009).

Immunoglobulin $\mathrm{G}$ is the only class of antibody that significantly crosses the human placenta, influenced by maternal level of IgG concentration and maternal age amongst other factors (Palmeiraet al, 2012). Further significant reductions, especially in IgG concentrations in these abnormal pregnancy conditions which has been reported to provide primary immunity in the newborn whose immunity is immature (Bunderset al, 2010; Palmeiraet al, 2012 and Malek, 2013), as detected in the current study therefore, will be indicative of poorly transferred secondary immunity in the children born to both pregnant diabetic and preeclamptic women. Thus, prompt detection and adequate management of these conditions by way of regular antenatal care would help in preventing any likely consequences due to the changes in the immunoglobulin levels.

\section{References}

[1]. Ahsan T, Wahab F, Kamal MM, Islam SN. Serum immunoglobulins (IgG, IgA, IgM) levels in preeclampsia and eclampsia pregnancies.Intern J Third World Med. 2009; 8(1): 1-4. http://print.ispub.com/api/0/ispub-article/11479 [accessed 17.11.15]

[2]. Akinlade KS, Arinola OG, Salimonu LS, Oyeyinka GO. Circulating immune complexes, immunoglobulin classes (IgG, IgA and $\operatorname{IgM}$ ) and complement components (C3c, C4 and Factor B) in diabetic Nigerians.WestAfr J Med. 2004; 23(3):253-255.

[3]. Akinpelu, OO, Aken'Ova, YA, Arinola, OG. Levels of immunoglobulin classes are not associated with severity of HIV infection in Nigerian patients. World Journal of AIDS. 2012; 2(3):232-236

[4]. Al-Jameil N, Aziz Khan F, Fareed Khan M, Tabassum H. A brief overview of preeclampsia.JClin Med Res. 2014; 6(1):1-7.

[5]. Amah-Tariah FS, Dapper DV and Ojeka SO. Haematological values in pregnant women in Port Harcourt, Nigeria II: Serum iron and transferrin, total and unsaturated iron binding capacity and some red cell and platelet indices. Niger J Physiol Sci. 2011; 26(2):173-178.

[6]. Arinola G, Arowojolu A, Bamgboye A, Akinwale A, Adeniyi A. Serum concentrations of immunoglobulins and acute phase proteins in Nigerian women with preeclampsia.Reprod Biol. 2006; 6(3):265-274.

[7]. Arulkumaran N, Lightstone L. Severe pre-eclampsia and hypertensive crises. Best Pract Res ClinObstetGynaecol. 2013; 27(6):877884.

[8]. Benster B, Wood EJ. Immunoglobulin levels in normal pregnancy and pregnancy complicated by hypertension.JObstetGynaecol Br Commonw. 1970; 77(6):518-522

[9]. BrownMA, LindheimerMD, de Swiet M, Van Assche A, MoutquinJM.The classification and diagnosis of the hypertensive disorders of pregnancy: statement from the International Society for the Study of Hypertension in Pregnancy (ISSHP). Hypertens Pregnancy 2001; 20:IX-XIV.

[10]. Bunders M, Pembrey L, Kuijpers T, Newell ML. Evidence of impact of maternal HIV infection on immunoglobulin levels in HIVexposed uninfected children. AIDS Res Hum Retroviruses. 2010; 26(9):967-975.

[11]. Dapper DV, Emem-Chioma P, Didia BC. Some hematological parameters and the prognostic value of CD4, CD8 and total lymphocyte counts and CD4/CD8 cell count ratio in healthy HIV sero-negative, healthy HIV sero-positive and AIDS subjects in Port Harcourt, Nigeria. Turk J Hematol 2008; 25(4):181-186.

[12]. Dapper DV, Nwauche CA, SiminialayiIM.Somehaematological reference values for pre-primary and primary school aged children in Port Harcourt, Nigeria. Niger J ClinPract. 2009; 12(3):262-267. 
Serum Immunoglobulin Changes In Pregnancy Complicated With Pre-Eclampsia And Diabetes...

[13]. França EL, Calderon Ide M, Vieira EL, Morceli G, Honorio-França AC. Transfer of maternalimmunity to newborns of diabeticmothers. Clin Dev Immunol.2012; 2012:928187. Epub2012 Sep 9.

[14]. Eiland E, Nzerue C, Faulkner M. Preeclampsia 2012. J Pregnancy. 2012; 2012: 586578. doi: 10.1155/2012/586578. Epub 2012 Jul 11.

[15]. Fischbach FT, Dunning MB III, eds. Manual of Laboratory and Diagnostic Tests, 8th ed. Philadelphia: Lippincott Williams and Wilkins. 2009

[16]. Fischer M. Serum immunoglobulins in diabetic and healthy pregnant patients and their newborn infants.ZentralblGynakol. 1984; 106 (20):1375-1380.

[17]. Georgieff MK. The effect of maternal diabetes during pregnancy on the neurodevelopment of offspring.Minn Med. 2006; 89(3):4447.

[18]. Jillian AN. The role of immunogenetic factors in the etiology of pre-eclamptic toxemia of human pregnancy. Volume 1. Thesis presented for the degree of Doctor of Medicine, University of Adelaide, Australia. March 1978.

[19]. Khirwadkar MA, Kher JR. Study of serum immunoglobulins in normal pregnancy. Indian J PhysiolPharmacol. 1991; 35(1):69-70.

[20]. Malek A. Role of IgG antibodies in association with placental function and immunologic diseases in human pregnancy. Expert Rev ClinImmunol. 2013; 9(3):235-249.

[21]. Obiandu C, Okerengwo AA, Dapper DV. Levels of serum immunoglobulins in apparently healthy children and adults in Port Harcourt, Nigeria. Niger J Physiol Sci. 2013; 28(1):23-27.

[22]. Ogbimi AO, Omu AE. Serum immunoglobulin levels in the course of normal gestation in Nigerian women. Afr J Med Med Sci. $1989 ; 18(2): 139-144$.

[23]. Al-HayaniNN. Study on some predeliveryimmunoparameters in pregnant women in Al-Ramadi city. J University Anbar Pure Sci. $2011 ; 5(2): 25-29$

[24]. Okerengwo AA, Williams AI, Ibeziako PA. Immunological studies on pre-eclampsia in Nigerian women. Int J Gynaecol Obstet. 1990; 33(2):121-125.

[25]. Palmeira P, Quinello C, Silveirra-Lessa AL; Zago CA and Carneiro-Sampaio M. IgG Placental Transfer in Healthy and Pathologic Pregnancies. Clin Dev Immunol. 2012; 2012: 985646.

[26]. Mustafa R, Ahmed S, Gupta A, Venuto RC. A comprehensive review of hypertension in pregnancy. J Pregnancy. 2012; 2012:105918. doi: 10.1155/2012/105918. Epub 2012 May 23.

[27]. WHO/JUNP [WorldHealth Organization/ Joint United Nations Programme on HIV/AIDS -UNAIDS], (1998): HIVIn Pregnancy: A Review.

\section{Legend to Tables}

Table 1: Values of the various immunoglobulin types obtained forall subjects.

Table 2a: Values of immunoglobulin A ( $\operatorname{IgA}$ ) obtained in the various trimesters of pregnancy amongst pregnant subjects

Table 2b: Values of immunoglobulin $\mathrm{G}(\mathrm{IgG})$ obtained in the various trimesters of pregnancy amongst pregnant subjects

Table 2c: Values of immunoglobulin $\mathrm{M}(\operatorname{IgM})$ obtained in the various trimesters of pregnancy amongst pregnant subjects

Table1

\begin{tabular}{|c|c|c|c|}
\hline Subject groups & $\begin{array}{l}\text { Immunoglobulin A } \\
(\mathrm{mg} / \mathrm{dl})\end{array}$ & $\begin{array}{l}\text { ImmunoglobulinG } \\
(\mathrm{mg} / \mathrm{dl})\end{array}$ & $\begin{array}{l}\text { ImmunoglobulinM } \\
(\mathrm{mg} / \mathrm{dl})\end{array}$ \\
\hline $\begin{array}{l}\text { Group A: Healthy non- } \\
\text { pregnant subjects }(n=50)\end{array}$ & $119.76 \pm 16.794$ & $3615.92 \pm 261.50$ & $238.68 \pm 38.38$ \\
\hline $\begin{array}{l}\text { Group B: Healthypregnant } \\
\text { subjects }(n=50)\end{array}$ & $130.24 \pm 14.0^{(\mathrm{a})}$ & $1529.00 \pm 88.11^{\text {(a) }}$ & $136.20 \pm 23.89^{(a)}$ \\
\hline $\begin{array}{l}\text { Group C: Subjects withpre- } \\
\text { eclampsia }(n=50)\end{array}$ & $132.08 \pm 15.99^{(\mathrm{a})}$ & $1366.67 \pm 67.26^{*(a)}$ & $172.67 \pm 29.19^{*(a)}$ \\
\hline $\begin{array}{l}\text { Group D: Subjects with } \\
\text { gestational diabetes }(n=50)\end{array}$ & $177.13 \pm 20.47 *^{(\mathrm{a})}$ & $1207.06 \pm 22.51^{*(a)}$ & $195.40 \pm 20.67 *^{(a)}$ \\
\hline
\end{tabular}

All values presented as Mean $\pm \mathrm{SD}$; * Values are significantly different compared to Group B subjects; (a) Values are significantly different compared to Group A subjects.

Table 2a:

\begin{tabular}{|l|l|l|l|}
\hline Groups & $\begin{array}{l}\text { First trimester } \\
(\mathrm{mg} / \mathrm{dl})\end{array}$ & $\begin{array}{l}\text { Second trimester } \\
(\mathrm{mg} / \mathrm{dl})\end{array}$ & $\begin{array}{l}\text { Third trimester } \\
(\mathrm{mg} / \mathrm{dl})\end{array}$ \\
\hline $\begin{array}{l}\text { Group B: Healthy pregnant } \\
\text { subjects }(\mathrm{n}=50)\end{array}$ & $133.30 \pm 29.02$ & $130.08 \pm 16.20$ & $128.05 \pm 18.01$ \\
\hline $\begin{array}{l}\text { Group C: Subjects withpre- } \\
\text { eclampsia (n=50) }\end{array}$ & - & $192.12 \pm 27.30^{*}$ & $233.09 \pm 13.18^{*}$ \\
\hline $\begin{array}{l}\text { Group D: Subjects with } \\
\text { gestational diabetes } \\
\text { (n=50) }\end{array}$ & $177.31 \pm 30.33^{*}$ & $176.26 \pm 22.19^{*}$ & $178.28 \pm 28.00^{*}$ \\
\hline
\end{tabular}

Values presented as Mean \pm SD; * mean values are significant different compared to Group B subjects. 
Serum Immunoglobulin Changes In Pregnancy Complicated With Pre-Eclampsia And Diabetes...

Table 2b:

\begin{tabular}{|l|l|l|l|}
\hline Groups & $\begin{array}{l}\text { First trimester } \\
(\mathrm{mg} / \mathrm{dl})\end{array}$ & $\begin{array}{l}\text { Second trimester } \\
(\mathrm{mg} / \mathrm{dl})\end{array}$ & $\begin{array}{l}\text { Third trimester } \\
(\mathrm{mg} / \mathrm{dl})\end{array}$ \\
\hline $\begin{array}{l}\text { Group B: Healthy pregnant } \\
\text { subjects }(\mathrm{n}=50)\end{array}$ & $1519.87 \pm 54.00$ & $1490.07 \pm 75.03$ & $1488.22 \pm 21.50$ \\
\hline $\begin{array}{l}\text { Group C: Subjects withpre- } \\
\text { eclampsia (n=50) }\end{array}$ & - & $1242.28 \pm 65.64 *$ & $1208.44 \pm 73.00 *$ \\
\hline $\begin{array}{l}\text { Group D: Subjects with } \\
\text { gestational diabetes } \\
(\mathrm{n}=50)\end{array}$ & $1359.37 \pm 27.98^{*}$ & $1168.13 \pm 42.04 *$ & $1198.19 \pm 38.20^{*}$ \\
\hline
\end{tabular}

Values presented as Mean $\pm \mathrm{SD} ; *$ mean values are significant different compared to Group B subjects.

Table 2c:

\begin{tabular}{|l|l|l|l|}
\hline Groups & $\begin{array}{l}\text { First trimester } \\
(\mathrm{mg} / \mathrm{dl})\end{array}$ & $\begin{array}{l}\text { Second trimester } \\
(\mathrm{mg} / \mathrm{dl})\end{array}$ & $\begin{array}{l}\text { Third trimester } \\
(\mathrm{mg} / \mathrm{dl})\end{array}$ \\
\hline $\begin{array}{l}\text { Group B: Healthy pregnant } \\
\text { subjects (n=50) }\end{array}$ & $135.57 \pm 25.02$ & $132.20 \pm 85.00$ & $129.89 \pm 40.10$ \\
\hline $\begin{array}{l}\text { Group C: Subjects withpre- } \\
\text { eclampsia (n=50) }\end{array}$ & - & $146.49 \pm 26.09^{*}$ & $182.76 \pm 15.87^{*}$ \\
\hline $\begin{array}{l}\text { Group D: Subjects with } \\
\text { gestational diabetes } \\
(\mathrm{n}=50)\end{array}$ & $186.31 \pm 31.00^{*}$ & $208.17 \pm 29.35^{*}$ & $185.26 \pm 44.31^{*}$ \\
\hline
\end{tabular}

Values presented as Mean $\pm \mathrm{SD} ; *$ mean values are significant different compared to Group B subjects. 